\title{
Public Lives, Private Lives: the Fundamental Dilemma in Political Biography
}

\section{Nicholas Brown}

The public life-private life division preoccupies Australian political biography - perhaps not peculiarly so, but certainly in distinctive terms. A consideration of the future of political biography might usefully begin by exploring this division, and asking not so much 'which side of the argument is right?' but seeking to identify what is invested in the issue, and how it reflects the uses to which we seek to put political biography. Such a consideration might tap directly into challenging the ways we construct ideas, policies, problems and solutions by imagining alternative approaches, particularly with reference to themes such leadership, representation and power.

As Tim Rowse noted, reflecting on the many ways in which it is easy for a biographer to disappoint, the reception of his Nugget Coombs: A reforming life (2002), and his concentration on the 'public' Coombs, prompted an almost iconic despair from Allan Patience. 'It is almost as if Australian maleness encompasses a seeming soullessness,' Patience despaired, 'or that it possesses an unknowable and perhaps stony heart, like the continent itself.' Where was the 'private' Coombs, or at least a sense of what motivated him, explained his values and accounted for the intersection between his career and other facets of his life? On the other side of the argument - and dealing specifically with political biography - James Walter (2002) has emphasised the necessarily public focus of the genre, dealing as it must with 'how people affect institutions and institutional change'. Further, Walter argued that because of the direct impact of the political sphere on our lives 'we want to understand not only leaders but types of leaders'. 'Political biography', he asserted, 'with its general aims of elucidating leadership, philosophy or institutions, has purposes beyond the individual life'. There is, then, an almost didactic, categorical imperative to a concentration on the public dimension of political lives, particularly given a recent emphasis on exploring the public rhetoric of 'social narratives' that are taken as so central to political influence. Walter concluded these comments, in an essay on Paul Hasluck as 'citizen biographer', by endorsing Judith Brett's view in her study of Menzies that 'the public man is the real man and the task is to read his character where we find it - in public life'.

I am not sure whether, in offering this assessment in Robert Menzies' Forgotten People, Brett (1992) was recommending a general theorem or accounting for 
specific characteristics of her man in his context: the most subtle of her chapters in Australian Liberals and the Moral Middle Class (2003) deals with a fusion of public and private around the concept of 'sound finance' and the figure of Joseph Lyons - a study which deals not so much a discrete domain of public rhetoric but with intersecting social networks, 'citizens' movements' and discursive shifts in economics and moral injunction. But, either way, we have a polarity: bluntly, on the one hand, a persistent disappointment at the failure of Australian biography to push beyond the public surface of the subject; on the other, an injunction that it is primarily the public domain of the subject that is the essential concern of the political biographer. What should we do with these contending approaches?

In these brief comments, I want to begin by surveying currents of debate in reviews of political biographies, seeking to develop a general sense of use and expectation surrounding the genre without getting caught up in cursory assessments of individual intention and performance. This quick scan confirms a fairly evenly-balanced division between reviewers who regret pages wasted on years outside political office, and those who judge that the breathless details of career obscured an understanding of the subject. No critic was more scarifying on this issue than Rodney Cavalier (2001), reviewing David Day's John Curtin: A life (2000). Cavalier alleged Day paid no attention to the vital issues of factional and political management that Curtin confronted: pages that should have been devoted to the enormity of those challenges, Cavalier objected, were given instead to 'neuritis and Christmas'. Day, for his part, has advocated moving beyond the 'traditional, top-heavy, political biography' to understand emotional and psychological issues, and more fundamentally private issues of shame, guilt and dependency. Cavalier was not convinced. Day's 'end product', he judged, was not a political biography. Rather, the 'facile attention to the social and political forces driving both sides of politics', Cavalier swiped, 'is more akin to writing words for balloons in a comic strip, pictures not supplied'.

It can, then, get nasty. And it can also seem that political biography, in such a debate, is allocated the fairly meagre role of confirming a public record (a role perhaps like that noted of recent literary biographies, where - presumably under commercial pressure - a detailed intellectual engagement with the subject gives way simply to a chronicle of works and personalities). What is at stake in these disputes? Two things: a continuing interrogation of the political domain itself - one that might be attuned to how this sphere is created, and changes in its dynamism, rather than being taken-as-a-given; and an opportunity to assess the concepts of public and private as they, too, are products of social and political change, with a fair degree of traffic between them. As Kay Ferres has observed, seeking especially to incorporate concepts of gender into the customary domains of biography, the genre itself 'can be a catalyst of dispute and disagreement about the public interest [what defines it, and is encompassed by it] as well as 
a document of public lives and careers'. What questions/opportunities might Australian political biography, and the political scientists who use it, be missing in this categorical preoccupation with the public-private divide?

'Political lives', a recent British academic reviewer regretted, were becoming an over-worked genre, reflecting 'a fetish for the ins-and-outs of the political class and moving away from interests in the events and ideas that have shaped modern society'. In contrast, Troy Bramson (2003), reviewing one of the two biographical studies of Bob Carr that emerged in early 2003, greeted the West and Morris book (2003) as 'a welcome addition to the burgeoning field of Australian political biography'. This growing field was defined - in part by its subjects, such as Carr - less by ideology or commitment and more by the mechanisms of leadership, ambition and personality (Bramson savoured Carr's admission that 'to be a good leader you must occasionally be a good butcher'). This sense of politics seems to provide the space in which Australian political biography as a concept, an exercise and a commodity - flourishes, almost despite itself. Allan Patience, this time welcoming Jenny Hocking's study of Lionel Murphy (1997) (explicitly sub-titled 'a political biography', without really explaining why) as warranting immediate placement 'in the vanguard of Australian political biography', prefaced his review by defining the context for such studies thus: 'Australian politics is best understood in terms of meretricious populism. Its factional elites and cliques publicly parade their pretensions to egalitarianism while behind the scenes they mostly practice a mindless adversarialism, boyo-cronyism and payback politics'. With this as an assumption about what defines the political - and with the inevitable dialectics and explanatory resources it establishes (outsiders/insiders, numbers men, levellers, etc.) - we might begin to wonder whether the end product of Australian political biography is in danger being predetermined by the political processes it purports to describe.

One question we might consider, then, is whether such an interdependence between characterisations of Australian politics and the biographical interest in Australian politicians is altogether healthy. A quick reply might be: 'well, that's how Australian politics is: accept it'. A reviewer of Margaret Simons' essay on Mark Latham in May 2004 suggested that Latham might be 'thanked for the rebirth of the political biography' in Australia - the individual trajectory of a Westie becoming a Whitlam protégé and embodying the new values, morality and experience of aspirational Australia. For a moment, Latham peculiarly embodied/celebrated/created a powerful nexus of biography (public and private) and politics. Yet look what had happened to him by October, as an election run on hasty, superficial policies, uncontested assertions and the 'leadership-as-trust' refrain claimed him completely as its victim. 
But is it as simple as that? Might other lessons be drawn from the ways leaders inhabit what they call 'public life' - in itself a very revealing formulation, one which might be contrasted to an older concept of 'public office' in its coupling of a personalized ethical pledge to live the duties of high office through an assumed continuum between leader and people, yet which in turn allows an often very convenient departure from the conventions of a leader's responsibility for the arcane, messy, complex and hidden processes of government, of office ('I was not told ...' ' 'I did not know ...'). How might we define the public domain of leadership in the wake of the Hutton Inquiry in Britain ${ }^{1}$ or A Certain Maritime Incident ${ }^{2}$ in Australia? As Richard Sennett has already suggested, the 'public', perhaps especially as it is defined by and around politicians, is not as unchanging, self-evident or straight-forward as we like to think: the first call for a biographer might be to ensure that they explore the kind of historical nuances shaping how that sphere is constructed in context.

So long as each side of political biography (the space and game of politics on the one hand and the identification of the biographical subject on the other) remain so mutually reinforcing and justifying, there is unlikely to be much reconsideration of either. So long as the questions asked of one are pretty much the same as the questions asked of the other, we have a stasis, if not a stalemate. Archetypes, as Neal Blewett has observed - from a vantage both inside and outside the domain of politics - are perhaps predestined to dominate political biography and even autobiography, at the expense of 'private selves' and all that they might represent.

How might we move on this situation? First, perhaps, by closely scrutinising the assumptions we work with. Graham Little (1988) noted that the 'rage for strong leadership' during the 1980s — he was referring to Thatcher, Reagan and Fraser in particular - reflected the distinct role of such politicians as 'moral guides through the uncertainties of the age'. These figures represented a politics that, Little suggested, took on 'what the rest of us have given up on, or are making a mess of' (Little 1988). In that context, in a political culture overshadowed by the strained boundaries of expectations and rights from the 1970s but not yet enmeshed in the ambiguities of globalisation and reconstruction of the 1990s, the prejudices of such leaders were their strengths, and the control they exercised on political agendas remedied the alienation experienced among those who supported them. But are we in the same place now? What kinds of questions might we now bring to assessments of the link between the 'public' of the politician and the 'private' of those who look to them for leadership the experience of 'middle Australia' as surveyed by Michael Pusey (2003), for example? Laments at the failure of contemporary political leadership - its careerism, evasions of responsibility and populism - are widespread. But to what extent do such characterisations of politics and leadership need accommodate changes in political agendas (post materialism, the politics of 
identity rather than identity politics, issues that no longer fit with ideological continuums, and so on) or the more fundamental ways in which, so Wendy Brown (1995) argued, a universalised liberal entitlement project has produced its own inherent contradictions in individualised normative identity? It is exactly in asking such questions that political biography might serve as a catalyst in rethinking what we mean by public and private in the first place.

Interestingly, in the remarks quoted above, Neal Blewett went on to suggest the need not necessarily for more intimate, private reflections by/on politicians but for 'grander public myths' that might anchor political lives in meaning. Seen from this perspective, perhaps the public-private distinction is not itself especially useful: the point is more about the kinds of questions we seek to answer through it. It is significant that one of the most consistently favourably reviewed recent Australian political biographies is Paul Strangio's study of Jim Cairns, Keeper of the Faith (2002): that aspects of that book most often praised centre on Strangio's success in balancing, with both complexity and dignity, Cairns' political failure and his intellectual integrity. It is not that we are being asked to see a private Cairns behind the public face, but that, in powerful ways, the book prompts an exploration of the evolution of identity in shifting political, personal and social contexts that make such divisions seem superfluous. Similarly, part of the success of Marilyn Lake's study of Faith Bandler has been identified in the subtlety with which Lake registered the costs to Bandler's persona and power amid the transition from 'the politics of persuasion' to 'the politics of representation'; and from discourses of equal rights to those of land rights (2002).

This leads to my second point. What has been recently described as the biographical turn' in the social sciences offers a perspective on these issues through an increasing interest in questions of: reflexivity, individualisation and agency that reflect both structural and humanist levels of analysis; and, the construction rather than deconstruction of subjects, premised on understanding specific, enabling contexts of action and amounting to more than the realization of identities or pathologies in identities and psychologies. The concept of reflexivity registers the inherently social nature of the self: its basis in exchange; its embodiment in gesture and disposition. Stuart Macintyre noticed these features well in his study of Syme, Deakin and Higinbotham, demonstrating how their political alignments were in many ways reinforced by patterns of sociability, comportment, manners - what might be termed their habitus: an embodied, enacted and mutual subjectivity (1991). Judith Allen achieved something similar in her study of Rose Scott (1994). It is significant that a biographical approach figures so prominently in recent studies of women in Australian politics, and perhaps especially of 'conservative' women (Michael McKernan's Beryl Beaurepaire (1999); Margaret Fitzherbert's Liberal Women (2004), directly testing and challenging the public/private divide as it figures in the lives of those who, experientially or philosophically, might be most 
assumed to be its subjects. Such codes of sociability are perhaps easier to decipher in Victorian and Edwardian contexts, and among multiple subjects, and away from the relentlessly masculinised domain of top political leadership. But we need such an approach - a full contextualisation of political manners and agency - if we are to understand the current domain of politics and of politicians, and to make sense of how we got here.

My third and final point might seem like advertising, but is about something more. The Australian Dictionary of Biography is preparing to release the august $A D B$ as a fully-searchable, integrated website. It is easy to get distracted on websites, as evident in an attempt to define the political sphere through the still incomplete, experimental test-site of the $A D B$ Online: a search by politician gives us 1611 matches to individual entries; politics gives us 1233; political gives 1910; public servant gives us 1482. Of the 50 links to the use of the word 'frustration', 9 are to politicians; of the 161 to 'compromise', 68 are to politicians; of the 275 to 'ambition', 52 are to 'politicians'; 7 of the 33 (20\%) examples of 'envy' are to politicians, as opposed to 9 of the 94 (or 10\%) to 'compassion' and 16 of the 142 to 'wisdom'. A large majority of the mentions of 'oratory' are to politicians what will be the skill that dominates as we move into the more contemporary period? Of the 556 mentions of 'radical', politicians figure as a large minority among a diverse mix, but they account for the clear majority of 'conservative'. And so on.

But beyond this random sample, I want to suggest a more important point. A resource like the $A D B$ Online, as it evolves, is not just a technical tool to do what we do any way but more efficiently; it has the capacity to shape and enable new research agendas, and even to be an agent in recasting questions that are appropriate to the changing interests and questions we will bring to biography. In its first release, later this year, for example, a search on Edmund Barton will take you to the $A D B$ entry itself, then on to linked resources (guides to relevant papers, collections, sources), one such link being to the digitised Barton papers at the National Library of Australia, including items ranging from correspondence, diaries and photographs through to newspaper cuttings and menus. As the capacity of the $A D B$ Online develops through to links to other collecting institutions - such as Screen Sound Australia, the National Museum - imagine what might be done to 'embody' the lives of political figures, not just as individuals but as figures who can be contextualised in their networks, their opportunities, their experiences, their gestures, memberships, friendships, even their geographies and mobility. But, as I said, this is not just a technical resource. The information age, as Manuel Castells noted (for good or ill), is one in which 'people produce forms of sociability rather than follow modes of behaviour'. So the information age, and the new modes of biography it will encourage/require us to produce, might allow us to explore the history of such forms of sociability - again, refiguring our sense of the relation between the 
political, the public and the private. Rather than coming to biography - as the iconic big, fat book - to confirm the public record, we might find that we use biography to ask rather different questions of what constitutes a sense of the public in the first place.

\section{ENDNOTES}

1 The Hutton Inquiry was a British judicial inquiry chaired by Lord Hutton, appointed by the United Kingdom Labour government to investigate the death of a government weapons expert, Dr David Kelly. The inquiry opened in August 2003 and reported on January 28, 2004. Its terms of reference were to "urgently [...] conduct an investigation into the circumstances surrounding the death of Dr. Kelly". (From Wikipedia, http://en.wikipedia.org/wiki/Hutton_Inquiry).

2 Senate Select Committee on a Certain Maritime Incident (2002), Select Committee on a Certain Maritime Incident report, Parliamentary paper (Australia. Parliament) no. 498. The Select Committee addressed, inter alia, the so-called 'children overboard' incident involving the HMAS Adelaide and the vessel known as SIEV 4, and the management of information concerning that incident by the Federal Government and Commonwealth agencies. 